\title{
Lactosphaera gen. nov., a New Genus of Lactic Acid Bacteria, and Transfer of Ruminococcus pasteurii Schink 1984 to Lactosphaera pasteurii comb. nov.
}

\author{
PETER H. JANSSEN, ${ }^{1,2 *}$ STEFAN EVERS, ${ }^{3}$ FREDERICK A. RAINEY, ${ }^{2,4}$ NORBERT WEISS, ${ }^{4}$ \\ WOLFGANG LUDWIG, ${ }^{3}$ CHRIS G. HARFOOT, $^{2}$ AND BERNHARD SCHINK ${ }^{1}$ \\ Fakultät für Biologie, Universität Konstanz, D-78434 Konstanz, ${ }^{1}$ Lehrstuhl für Mikrobiologie, Technische Universität \\ München, D-80333 Munich, ${ }^{3}$ and Deutsche Sammlung von Mikroorganismen und Zellkulturen GmbH, \\ D-38124 Braunschweig, ${ }^{4}$ Germany; and Department of Biological Sciences, \\ University of Waikato, Hamilton, New Zealand ${ }^{2}$
}

\begin{abstract}
The phylogenetic position and physiology of strain $\mathrm{KoTa}^{\mathrm{T}}(\mathrm{T}=$ type strain), which was previously classified as a Ruminococcus pasteurii strain, were studied. A determination of the $16 \mathrm{~S}$ ribosomal DNA sequence of this taxon revealed its position within the radiation of the gram-positive lactic acid bacteria having low DNA G+C contents and that it is closely related to the genus Carnobacterium. L-Lactic acid was produced from glucose by a fructose-1,6-bisphosphate-activated lactate dehydrogenase, and oxygen tolerance was observed, characteristics which are consistent with assignment to this group. On the basis of its phenotypic characteristics and unique signature nucleotides, we propose that strain KoTa2 (= DSM $2381=$ ATCC 35945) should be transferred to a new genus, Lactosphaera gen. nov., as the type strain of the species Lactosphaera pasteurii comb. nov.
\end{abstract}

The species Ruminococcus pasteurii was originally described to encompass L-tartrate-fermenting anaerobic cocci (27). This bacterium is able to ferment L-tartrate, citrate, oxaloacetate, pyruvate, and a variety of sugars, and the fermentation products have been reported to be acetate, formate, ethanol, and carbon dioxide (27). On the basis of the following characteristics of strain $\mathrm{KoTa}^{\mathrm{T}}$ ( $\mathrm{T}=$ type strain) (27), the original assignment of this organism to the genus Ruminococcus seemed to be justified: morphology, the fermentation end products, and the $\mathrm{G}+\mathrm{C}$ content of the DNA. However, our investigations showed that the type strain of $R$. pasteurii, strain $\mathrm{KoTa}$, is not physiologically or genetically related to other members of the genus Ruminococcus. The production of significant amounts of lactic acid, aerotolerance, and the results of a 16 S ribosomal DNA (rDNA) sequence analysis indicated that this strain, previously classified as a $R$. pasteurii strain, belongs to a new taxon of lactic acid bacteria. Therefore, we describe a new genus, Lactosphaera, and designate the type strain of $R$. pasteurii, strain KoTa2 (= DSM 2381), the type strain of a new species, Lactosphaera pasteurii comb. nov.

\section{MATERIALS AND METHODS}

Strain and media. Strain $\mathrm{KoTa} 2^{\mathrm{T}}$, which was originally described as a $R$. pasteurii strain (27), was obtained from our collection. Ruminococcus flavefaciens C94 (= ATCC 19208) was purchased from the American Type Culture Collection, Rockville, Md.

A freshwater mineral medium supplemented with vitamins (27) was used to cultivate strain $\mathrm{KoTa}_{2} \mathrm{~T}$. Yeast extract was added at a concentration of $0.02 \%$ (wt/vol) unless noted otherwise. Substrate tests were performed by using sugars (D isomers) at an initial concentration of $2 \mathrm{mM}$ and organic acids ( $\mathrm{L}$ isomers) at a concentration of $10 \mathrm{mM}$. Polysaccharides were added at a concentration of $0.1 \%(w t / v o l)$. All cultures were incubated at $34^{\circ} \mathrm{C}$. The buffers $2-(N$-morpholino)ethanesulfonic acid (MES), 3-( $N$-morpholino)propanesulfonic acid (MOPS) and $N$-(2-hydroxyethyl)-piperazine- $N^{\prime}$-(3-propanesulfonic acid) (EPPS) were purchased from Sigma Chemical Co., St. Louis, Mo., and the $\mathrm{pH}$ of each medium

* Corresponding author. Present address: Max-Planck-Institut für Terrestrische Mikrobiologie, D-35043 Marburg, Germany. Fax: (49) 6421161470. was adjusted to the appropriate value with $\mathrm{NaOH}$. Acetate agar (which contained $15 \mathrm{~g}$ of agar per liter) was prepared as described by Atlas and Parks (1)

Lactic acid production and metabolic studies. High-performance liquid chromatography and gas chromatography with a thermal conductivity detector were performed as described previously (17). The isomeric form of lactic acid was determined enzymatically (2) by using D- and L-lactic acid dehydrogenases (LDHs) (Boehringer, Mannheim, Germany). Growth yields were determined as described previously (16).

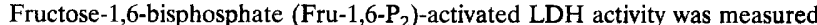
at $34^{\circ} \mathrm{C}$ as described elsewhere (21). Fru-1,6- $\mathrm{P}_{2}$-independent $\mathrm{LDH}$ activity was measured by the same method except that Fru-1,6- $\mathrm{P}_{2}$ was omitted.

Further characterization of strain $\mathrm{KoTa} 2^{\mathrm{T}}$ was carried out by using previously described methods $(15-17,25)$

Peptidoglycan analysis. Cell walls were prepared and the peptidoglycan structure was determined by the methods of Schleifer and Kandler (28), modified by using thin-layer chromatography on cellulose sheets instead of paper chromatography. Briefly, $1 \mathrm{mg}$ of freeze-dried cell wall material was hydrolyzed in $0.2 \mathrm{ml}$ of $4 \mathrm{M} \mathrm{HCl}$ at $100^{\circ} \mathrm{C}$ for $16 \mathrm{~h}$ (total hydrolysate) or $45 \mathrm{~min}$ (partial hydrolysate). The diamino acids in the total hydrolysate were identified by one-dimensional chromatography by using methanol-pyridine-water-10 $\mathrm{M} \mathrm{HCl}(32: 4: 7: 1, \mathrm{vol} / \mathrm{vol} /$ $\mathrm{vol} / \mathrm{vol})$. The amino acids and peptides in the partial and total hydrolysates were identified by their mobilities and staining characteristics with ninhydrin spray after two-dimensional chromatography $(28)$. The resulting "fingerprints" were compared with those of known peptidoglycan structures.

Oxygen tolerance. Oxygen was added to the desired concentration with a syringe to sealed 120 -ml serum vials containing (under an $\mathrm{N}_{2}-\mathrm{CO}_{2}$ [80:20] atmosphere) $50 \mathrm{ml}$ of anoxic medium supplemented with $10 \mathrm{mM}$ sodium L-tartrate and $2 \mathrm{mM} \mathrm{Na} \mathrm{S}_{2} \mathrm{~S}_{3}$ but no sulfide reductant. Hemin and hematin were added from filter-sterilized (pore size, $0.2 \mu \mathrm{m}$ ) stock solutions in $2 \%$ methylamine, so that the final methylamine concentration was $0.9 \mathrm{mM}$.

Catalase (29) and superoxide dismutase (33) activities were assayed by using cell extracts that were prepared by French press treatment under anoxic conditions (18).

16S rDNA analysis. Purification of genomic DNA, in vitro amplification of $16 \mathrm{~S}$ rRNA genes, and a direct sequence analysis of amplified DNA fragments were performed with strain $\mathrm{KoTa} 2^{\mathrm{T}}$ and $R$. flavefaciens as described elsewhere (26, 30 ). The derived $16 \mathrm{~S}$ rRNA primary structure of strain $\mathrm{KoTa}^{\mathrm{T}}$ was added to an alignment of about 1,800 homologous sequences from bacteria. The phylogenetic affiliation of strain $\mathrm{KoTa}^{\mathrm{T}}$ was determined by using distance matrix and maximum-parsimony methods and a data set containing all of the available 16S rRNA sequences from gram-positive bacteria having low genomic DNA G+C contents. Subsets of the data were analyzed by using a maximum-likelihood-based treeing procedure. The reference sequences used were obtained from public databases $(22,24)$. The complete sequences were used to analyze close relationships, whereas the more variable sequence positions (positions at which the sequences were invariant in less than $50 \%$ of the sequences in the entire data set) were deleted to investigate remote relationships. The data analyses were performed by 
TABLE 1. Overall levels of similarity (values at lower left) of the $16 \mathrm{~S}$ rRNA primary structures of strain KoTa2 ${ }^{\mathrm{T}}$, Carnobacterium spp., selected lactic acid bacteria, and other bacteria, including members of the genus Ruminococcus

\begin{tabular}{|c|c|c|c|c|c|c|c|}
\hline \multirow[b]{2}{*}{ Organism } & \multicolumn{7}{|c|}{$\%$ Similarity ${ }^{a}$} \\
\hline & $\begin{array}{l}\text { Strain } \\
\text { KoTa2 }^{\mathrm{T}}\end{array}$ & $\begin{array}{l}\text { Carnobacterium } \\
\text { alterfunditum }\end{array}$ & $\begin{array}{l}\text { Camobacterium } \\
\text { divergens }\end{array}$ & $\begin{array}{l}\text { Carnobacterium } \\
\text { funditum }\end{array}$ & $\begin{array}{l}\text { Carnobacterium } \\
\text { gallinarum }\end{array}$ & $\begin{array}{c}\text { Camobacterium } \\
\text { mobile }\end{array}$ & $\begin{array}{l}\text { Carnobacterium } \\
\text { piscicola }\end{array}$ \\
\hline Strain $\mathrm{KoTa}^{\prime}{ }^{\mathrm{T}}$ & & 95.6 & 95.0 & 95.6 & 95.0 & 95.1 & 95.2 \\
\hline Carnobacterium alterfunditum & 94.6 & & 96.5 & 97.2 & 96.1 & 96.5 & 96.5 \\
\hline Carnobacterium divergens & 94.1 & 95.3 & & 96.5 & 96.9 & 96.1 & 97.2 \\
\hline Camobacterium funditum & 94.2 & 95.9 & 95.5 & & 96.1 & 97.7 & 96.5 \\
\hline Camobacterium gallinarum & 94.3 & 94.9 & 96.7 & 95.0 & & 96.0 & 98.2 \\
\hline Carnobacterium mobile & 95.1 & 96.5 & 96.3 & 97.7 & 96.1 & & 96.3 \\
\hline Camobacterium piscicola & 94.2 & 95.2 & 96.9 & 95.4 & 98.0 & 96.4 & \\
\hline Enterococcus faecalis & 92.0 & 92.6 & 92.6 & 93.8 & 92.1 & 93.6 & 92.0 \\
\hline Vagococcus fluvialis & 92.6 & 92.1 & 92.5 & 91.9 & 91.1 & 93.3 & 91.8 \\
\hline Lactococcus lactis & 87.2 & 87.8 & 87.0 & 87.1 & 86.2 & 87.3 & 86.3 \\
\hline Streptococcus thermophilus & 87.0 & 87.5 & 88.2 & 87.6 & 87.3 & 87.4 & 87.5 \\
\hline Bacillus subtilis & 91.2 & 90.3 & 90.2 & 90.0 & 90.3 & 90.1 & 90.3 \\
\hline Ruminococcus flavefaciens & 83.0 & 81.1 & 81.7 & 81.7 & 81.1 & 81.5 & 81.3 \\
\hline Ruminococcus gnavus & 76.1 & 75.8 & 75.8 & 75.9 & 74.7 & 76.1 & 75.4 \\
\hline Ruminococcus hansenii & 75.2 & 74.8 & 75.5 & 75.1 & 74.5 & 75.7 & 75.0 \\
\hline Ruminococcus productus & 78.7 & 78.1 & 78.6 & 77.5 & 77.3 & 78.5 & 78.0 \\
\hline Ruminococcus torques & 79.1 & 79.1 & 79.2 & 78.9 & 78.2 & 79.7 & 78.8 \\
\hline Escherichia coli & 78.4 & 78.4 & 78.1 & 77.5 & 77.4 & 78.0 & 77.5 \\
\hline
\end{tabular}

${ }^{a}$ The values on the upper right were calculated by using only data for positions that had been unambiguously determined for all members of the genus Carnobacterium.

using the ARB program package (23) and the treeing programs NEIGHBOR (8) and fastDNAm1 (22)

Nucleotide sequence accession numbers. The nucleotide sequences of strain $\mathrm{KoTa} 2^{\mathrm{T}}$ and $R$. flavefaciens have been deposited in the EMBL data library under accession numbers X85097 and X87150, respectively.

\section{RESULTS}

16S rDNA sequence analysis. Almost complete $16 \mathrm{~S}$ rRNA genes of strain $\mathrm{KoTa} 2^{\mathrm{T}}$ and $R$. flavefaciens were amplified in vitro and sequenced directly. Different treeing methods and different data sets were used to reconstruct the phylogenetic relationships of strain $\mathrm{KoTa}^{\mathrm{T}}$. Strain $\mathrm{KoTa}^{\mathrm{T}}$ is only distantly related to members of the genus Ruminococcus $(4,6,7)$, but is closely related to members of the genus Carnobacterium $(9,11$, 34). The overall levels of sequence similarity for strain $\mathrm{KoTa} 2^{\mathrm{T}}$, members of the genus Carnobacterium, selected lactic acid bacteria, and other bacteria are shown in Table 1 . The close phylogenetic relationship between strain KoTa2 ${ }^{\mathrm{T}}$ and members of the genus Carnobacterium is shown in Fig. 1. The position of this group among the lactic acid bacteria is shown in Fig. 2. True members of the genus Ruminococcus are included in Fig. 2 to show the great phylogenetic distance between these organisms and strain KoTa2 ${ }^{\mathrm{T}}$.

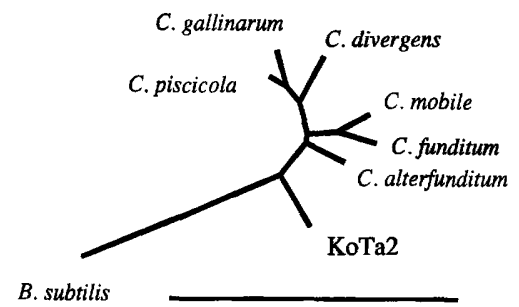

FIG. 1. Phylogenetic tree derived from 16S rDNA sequence analysis, reflecting the relationships of strain $\mathrm{KoTa}_{2}{ }^{\mathrm{T}}$ and members of the genus Carnobacterium. The tree was reconstructed by using a maximum-likelihood method. Bar = $10 \%$ estimated sequence divergence. Abbreviations: B., Bacillus; $C$., Carnobacterium.
Peptidoglycan structure. Purified cell walls of strain KoTa2 ${ }^{\mathrm{T}}$ contained the amino acids lysine, glutamic acid, aspartic acid, and alanine at a molar ratio of 1:1:1:2. The fingerprints of the partial hydrolysate and the presence of the hydrolysis-stable compound $\varepsilon$-(aminosuccinyl-)lysine are compatible only with peptidoglycan type A4 $\alpha$, L-Lys-D-Asp.

Oxygen tolerance. Strain KoTa2 ${ }^{\mathrm{T}}$ was able to grow in mineral medium containing $10 \mathrm{mM}$ L-tartrate but no sulfide reductant (with $2 \mathrm{mM} \mathrm{Na} \mathrm{S}_{2} \mathrm{O}_{3}$ added as a sulfur source) in the absence of yeast extract. Addition of $2.5 \%$ (vol $/ \mathrm{vol}$ ) $\mathrm{O}_{2}$ to the headspace of static cultures inhibited growth, but this inhibition was overcome by the addition of yeast extract. Strain $\mathrm{KoTa} 2^{\mathrm{T}}$ grew well on unreduced medium supplemented with 2 $\mathrm{mM} \mathrm{Na} \mathrm{S}_{2} \mathrm{~S}_{2} \mathrm{O}_{3}$ and $0.02 \%$ (wt/vol) yeast extract in the presence of $\mathrm{O}_{2}$ partial pressures up to $10 \%(\mathrm{vol} / \mathrm{vol})$. When the $\mathrm{O}_{2}$ partial pressure was between 10 and $16 \%(\mathrm{vol} / \mathrm{vol})$, growth was poor, while no growth occurred when the $\mathrm{O}_{2}$ partial pressure was greater than $18 \%(\mathrm{vol} / \mathrm{vol})$. In the presence of $5 \%$ ( $\mathrm{vol} / \mathrm{vol})$ $\mathrm{O}_{2}$, the amount of acetate produced from L-tartrate was not significantly changed, but a decrease in formate formation was detected (Table 2). There was no significant increase in the specific growth yield in the presence of oxygen.

Addition of $10 \mu \mathrm{M}$ hemin or $10 \mu \mathrm{M}$ hematin (dissolved in methylamine so the final methylamine concentration was 0.9 $\mathrm{mM}$ ) or addition of $10 \mu \mathrm{M} \mathrm{MnCl}_{2}$ did not overcome the growth inhibition caused by the presence of $2.5 \%$ (vol $/ \mathrm{vol}$ ) $\mathrm{O}_{2}$ in the headspace in the absence of yeast extract. Methylamine at a concentration of $0.9 \mathrm{mM}$ did not inhibit growth in the presence of $2.5 \%$ (vol/vol) $\mathrm{O}_{2}$ when the medium contained $0.02 \%$ (wt/vol) yeast extract. No superoxide dismutase or catalase activity was observed in cell extracts prepared from cells grown in the presence of $2.5 \%$ ( $\mathrm{vol} / \mathrm{vol}) \mathrm{O}_{2}$ with $10 \mathrm{mM} \mathrm{L-}$ tartrate and $0.02 \%(\mathrm{wt} / \mathrm{vol})$ yeast extract. However, growth occurred in the presence of air on Trypticase agar plates (12).

Carbon sources that support growth. Mannitol, sorbitol, and galactose supported growth of strain $\mathrm{KoTa}_{2}{ }^{\mathrm{T}}$, while ribose and glycerol did not. Strain KoTa $2^{\mathrm{T}}$ grew on starch and oat spelt xylan and grew weakly on laminarin. The following compounds did not support growth: chitin, gum karaya, carboxymethyl 


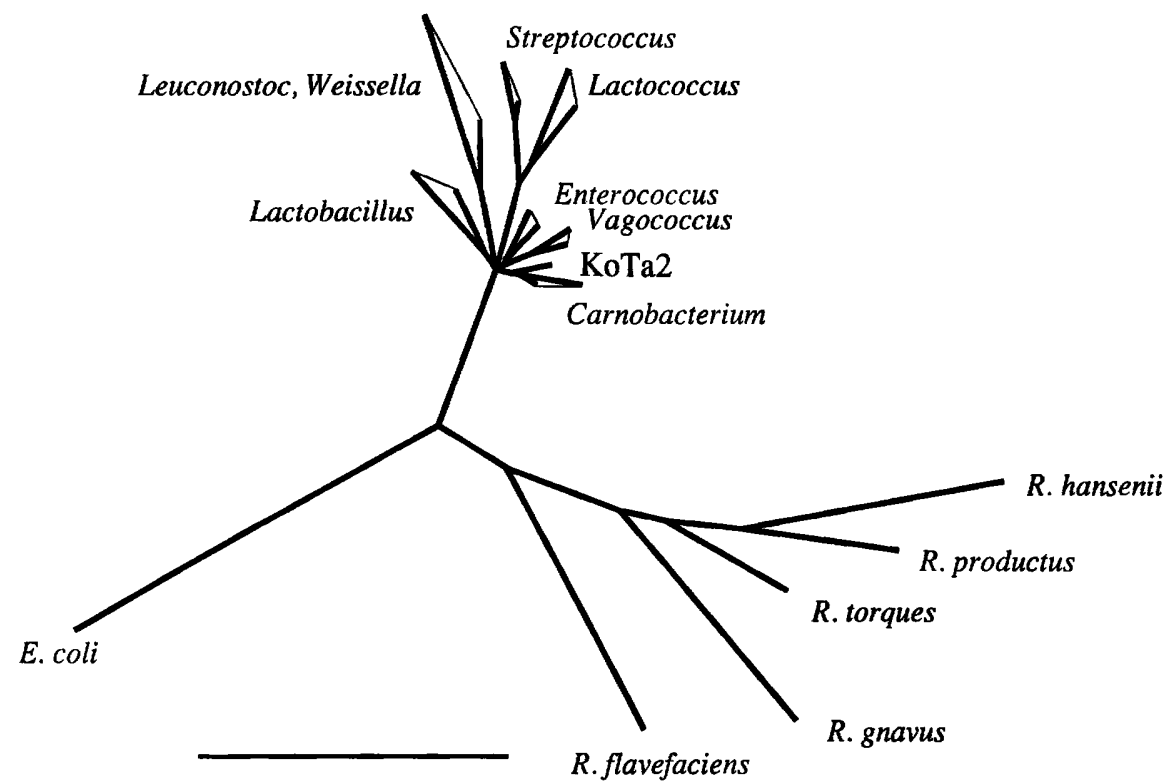

FIG. 2. Consensus tree showing the phylogenetic positions of strain $\mathrm{KoTa}_{2}{ }^{\mathrm{T}}$ and the genus Carnobacterium among the lactic acid bacteria and the distances between these taxa and the genus Ruminococcus. The tree was based on the results of maximum-likelihood analyses and was corrected by using the results of distance matrix and maximum-parsimony analyses. Only alignment positions which are occupied by identical nucleotides in at least $50 \%$ of all available $16 \mathrm{~S}$ rRNA sequences from gram-positive bacteria with low DNA G+C contents were included. The triangles indicate phylogenetic groups. Bar $=10 \%$ estimated sequence divergence. Abbreviations: E., Escherichia; R., Ruminococcus.

cellulose, amorphous cellulose, mannan, lichenan, carrageenan, gum locust bean, pullulan, arabinogalactan, and glycogen.

Fermentation of glucose. Strain $\mathrm{KoTa}_{2}{ }^{\mathrm{T}}$ produced L-lactate (in addition to formate, acetate, and ethanol) from a wide range of sugars, including glucose, fructose, maltose, lactose, sucrose, cellobiose, and sorbitol. Lactate was not formed from L-tartrate, pyruvate, or citrate.

Strain KoTa2 ${ }^{\mathrm{T}}$ was grown on $15 \mathrm{mM}$ glucose, and the end products of fermentation were determined (Table 3). Significant quantities of lactate were produced $(65 \%$ of the total product carbon), but very little hydrogen was produced. During growth the $\mathrm{pH}$ decreased from 7.2 to 5.5. The increase in lactate production was apparently not a consequence of the inclusion of yeast extract in the growth medium. The amount of lactate produced did not change when the level of yeast extract in the medium was varied from 0.01 to $0.1 \%$ (wt/vol) in the presence of $100 \mu \mathrm{g}$ of biotin per liter. Strain $\mathrm{KoTa}^{\mathrm{T}}$ also produced the same amount of lactate in the absence of yeast extract.

Lactate production in the presence of a range of $\mathrm{pH}$ values. Strain KoTa2 ${ }^{\mathrm{T}}$ was grown on $4 \mathrm{mM}$ glucose at different $\mathrm{pH}$ values by using heavily buffered media. The $\mathrm{pH}$ did not change during fermentation of glucose. The amount of lactate pro- duced (as a proportion of the total products) increased as the acidity of the growth medium increased (Fig. 3).

The LDH activity was higher in cultures grown at more acidic $\mathrm{pH}$ values than in cultures grown at more basic $\mathrm{pH}$ values (Table 4$)$. The LDH activity was very much lower ( 0 to $5 \%$ ) if Fru-1,6- $\mathrm{P}_{2}$ was omitted from the enzyme assay mixture. Cultures grown on L-tartrate or pyruvate did not produce lactate. Cells grown on pyruvate contained a Fru-1,6- $\mathrm{P}_{2}$-activated $\mathrm{LDH}$ activity, and this activity was higher in cells grown under more acidic conditions than in cells grown under more basic conditions.

Additional characteristics of strain $\mathrm{KoTa}^{\mathrm{T}}$. Esculin was hydrolyzed. Hydrogen in the headspace $\left(\mathrm{H}_{2}-\mathrm{CO}_{2}, 80: 20\right)$ did not inhibit growth on L-tartrate. Fumarate was not reduced. No growth occurred in the presence of $3 \%(\mathrm{wt} / \mathrm{vol}) \mathrm{NaCl}$, but growth did occur in the presence of $2 \%(\mathrm{wt} / \mathrm{vol}) \mathrm{NaCl}$. No growth occurred on acetate agar (pH 5.4).

\section{DISCUSSION}

$16 S$ rDNA sequence analysis. Our comparative 16S rDNA sequence analyses revealed that strain $\mathrm{KoTa}^{\mathrm{T}}$ is most closely related to the species of the genus Carnobacterium and is not

TABLE 2. Fermentation balances of strain $\mathrm{KoTa}^{\mathrm{T}}$ grown on L-tartrate in the absence and presence of oxygen ${ }^{a}$

\begin{tabular}{|c|c|c|c|c|c|c|c|}
\hline \multirow{2}{*}{$\begin{array}{c}\mathrm{O}_{2} \text { concn in } \\
\text { gas phase } \\
(\%)\end{array}$} & \multirow{2}{*}{$\begin{array}{l}\text { Amt of L-tartrate } \\
\text { degraded ( } \mu \mathrm{mol})\end{array}$} & \multicolumn{2}{|c|}{ Amt of products $(\mu \mathrm{mol})$} & \multirow{2}{*}{$\begin{array}{l}\text { Amt of cell } \\
\text { matter } \\
(\mathrm{mg})^{b}\end{array}$} & \multirow{2}{*}{$\begin{array}{l}\text { Amt of substrate } \\
\text { assimilated } \\
(\mu \mathrm{mol})^{c}\end{array}$} & \multirow{2}{*}{$\begin{array}{l}\% \text { Carbon } \\
\text { recovery }\end{array}$} & \multirow{2}{*}{$\begin{array}{c}\text { Ratio of formate } \\
\text { to acetate }\end{array}$} \\
\hline & & Formate & Acetate & & & & \\
\hline 0 & 500 & 426 & 441 & 6.66 & 110 & 106.9 & 0.97 \\
\hline 5 & 500 & 166 & 409 & 6.71 & 111 & 88.3 & 0.41 \\
\hline
\end{tabular}


TABLE 3. Fermentation balance of strain KoTa2 grown on $15 \mathrm{mM}$ glucose $\mathrm{c}^{a}$

\begin{tabular}{lccccc}
\hline \multirow{2}{*}{$\begin{array}{c}\text { Substrate } \\
\text { or product }\end{array}$} & \multicolumn{2}{c}{ Carbon balance } & & \multicolumn{2}{c}{ Hydrogen balance } \\
\cline { 2 - 3 } \cline { 5 - 6 } & $\begin{array}{c}\text { Amt } \\
(\mu \mathrm{mol})\end{array}$ & $\begin{array}{c}\mu \text { mol of } \\
\text { carbon }^{b}\end{array}$ & & $\begin{array}{c}\text { Amt of } \\
\text { available } \mathrm{H} \\
(\mu \mathrm{mol})^{b}\end{array}$ & $\begin{array}{c}\text { Redox } \\
\text { value } \\
(\mu \mathrm{mol})^{c}\end{array}$ \\
\hline Glucose & 750 & 4,500 & & 18,000 & 0 \\
Lactate & 867 & 2,601 & & 10,404 & 0 \\
Formate & 343 & 343 & & 686 & +343 \\
Acetate & 211 & 422 & & 1,688 & 0 \\
Ethanol & 323 & 646 & & 3,876 & -646 \\
$\mathrm{H}_{2}$ & 0.1 & 0 & & 0.2 & -0.2 \\
$\mathrm{CO}_{2}{ }^{d}$ & 191 & 191 & & 0 & +382 \\
$\mathrm{Cells}^{e}$ & 118 & 472 & & 2,006 & -59 \\
\hline
\end{tabular}

${ }^{a}$ The data are the means of the results of two independent experiments performed with $50-\mathrm{ml}$ cultures in the presence of $0.1 \%$ (wt/vol) yeast extract. The values were corrected for the products and cell matter $\left(9 \mathrm{mg} \cdot \operatorname{liter}^{-1}\right)$ produced on $0.01 \%$ (wt/vol) yeast extract.

${ }^{b}$ The balance was $104 \%$.

$c$ The balance was $1.03 \mu \mathrm{mol}$.

${ }^{d}$ The amount of $\mathrm{CO}_{2}$ was estimated (because we used a bicarbonate-buffered medium) as follows: micromoles of $\mathrm{CO}_{2}=$ millimoles of acetate + micromoles of ethanol - micromoles of formate.

e Cell dry weights were calculated from culture densities (optical densities at $650 \mathrm{~nm}$ ) by using conversion factors which were obtained by direct gravimetric determinations performed with 1 -liter cultures. Values were calculated by using $<\mathrm{C}_{4} \mathrm{H}_{7} \mathrm{O}_{3}>$ as the empirical formula for cell matter.

related to members of the genus Ruminococcus. The data indicated that the Carnobacterium species can be considered a phylogenetic unit that does not include strain $\mathrm{KoTa}_{2}^{\mathrm{T}}$. The levels of intrageneric similarity range from 94.9 to $98.0 \%$, while the corresponding values for strain $\mathrm{KoTa}_{2}{ }^{\mathrm{T}}$ and Carnobacterium species are 94.1 to $95.1 \%$. There is a slight overlap of values because of the high similarity value obtained for strain $\mathrm{KoTa}^{\mathrm{T}}$ and Carnobacterium mobile. However, most of the sequences of the Carnobacterium species are incomplete at their $3^{\prime}$ ends, and the sequence data for $C$. mobile do not include data for the $5^{\prime}$-terminal portion. Therefore, we also calculated similarity values based on only the homologous positions determined for all Carnobacterium spp. The values

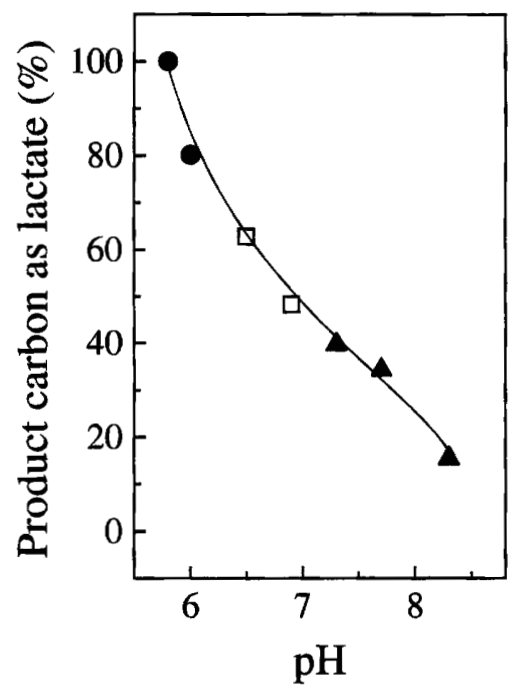

FIG. 3. Lactate production from glucose by strain $\mathrm{KoTa} 2^{\mathrm{T}}$ at different $\mathrm{pH}$ values. Symbols: $\boldsymbol{Q}$, MES buffer; $\square$, MOPS buffer; $\boldsymbol{\Lambda}$, EPPS buffer. All buffers were used at a concentration of $100 \mathrm{mM}$ and were adjusted to the required $\mathrm{pH}$ with $\mathrm{NaOH}$.
TABLE 4. Fru-1,6-P ${ }_{2}$-activated LDH activities in strain KoTa2 ${ }^{\mathrm{T}}$ grown on glucose and pyruvate at various $\mathrm{pH}$ values

\begin{tabular}{|c|c|c|c|c|}
\hline Substrate & $\begin{array}{c}\text { Growth } \\
\mathrm{pH}\end{array}$ & Buffer & $\begin{array}{l}\% \text { of product } \\
\text { carbon as } \\
\text { lactate }\end{array}$ & $\begin{array}{l}\text { Fru-1,6- } \mathrm{P}_{2} \text {-activated } \\
\text { LDH activity } \\
\left(\mu \mathrm{mol} \cdot \min ^{-1} \cdot \mathrm{mg}\right. \\
\text { of protein } \\
-1)^{a}\end{array}$ \\
\hline \multirow[t]{3}{*}{ Glucose } & 6.2 & MES & 74 & 0.419 \\
\hline & 7.1 & MOPS & 37 & 0.459 \\
\hline & 8.0 & EPPS & 26 & 0.113 \\
\hline \multirow[t]{3}{*}{ Pyruvate } & 6.2 & MES & 0 & 0.127 \\
\hline & 7.1 & MOPS & 0 & 0.129 \\
\hline & 8.0 & EPPS & 0 & 0.011 \\
\hline
\end{tabular}

${ }^{a}$ The Fru-1,6- $\mathrm{P}_{2}$-independent LDH activity was less than $5 \%$ of the Fru-1,6$\mathrm{P}_{2}$-activated $\mathrm{LDH}$ activity in all cases.

which we obtained are shown in Table 1 and support the congeneric status of the Carnobacterium spp. (similarity values, 96.0 to $98.2 \%$ ) and the exclusion of strain $\mathrm{KoTa}_{2}{ }^{\mathrm{T}}$ (similarity values, 95.0 to $95.6 \%$ ). The separation of these taxa is also reflected by the primary structure signatures. There are a number of residues in the $16 \mathrm{~S}$ rRNA primary structure of strain $\mathrm{KoTa}_{2}{ }^{\mathrm{T}}$ that differ from the residues in the Carnobacterium consensus sequence (Table 5), allowing strain KoTa2 ${ }^{\mathrm{T}}$ to be differentiated from members of the genus Carnobacterium. The tree in Fig. 1 shows the phylogenetic unity of the genus Carnobacterium and the somewhat remote position of strain $\mathrm{KoTa}_{2}{ }^{\mathrm{T}}$. This tree was reconstructed by using a maximumlikelihood method, and all alignment positions were included for the calculations. The 16S rRNA sequence of Bacillus subtilis, a moderately closely related outgroup reference organism, was used to root the tree. The topology of the tree was evaluated by using alternative treeing methods and various data sets that differed with respect to alignment positions and reference organisms. The branching pattern was stable in most cases. The tree in Fig. 2 shows the position of the strain $\mathrm{KoTa} 2^{\mathrm{T}}$-Carnobacterium cluster among the major groups of lactic acid bacteria. This tree is a consensus tree based on the results of a maximum-likelihood analysis that included $16 \mathrm{~S}$ rRNA sequences from all members of the cluster, selected

TABLE 5. Signature nucleotides in the $16 \mathrm{~S}$ rRNA primary structure of strain $\mathrm{KoTa} 2^{\mathrm{T}}$ which are different from the nucleotides in the consensus sequence of the genus Carnobacterium

\begin{tabular}{|c|c|c|}
\hline \multirow[b]{2}{*}{ Position $(s)^{a}$} & \multicolumn{2}{|c|}{ Nucleotide(s) in: } \\
\hline & Strain KoTa2 ${ }^{\mathrm{T}}$ & $\begin{array}{l}\text { Carnobacterium } \\
\text { consensus sequence }\end{array}$ \\
\hline 69 & $\mathrm{G}$ & $\mathrm{C}$ \\
\hline 156 & $\mathrm{C}$ & $\mathrm{U}$ \\
\hline 166 & $\mathrm{G}$ & A \\
\hline 210 & $\mathbf{U}$ & $\mathrm{C}$ \\
\hline $316 \cdot 337$ & $\mathbf{U} \cdot \mathbf{A}$ & $\mathrm{C} \cdot \mathrm{G}$ \\
\hline $443 \cdot 491$ & $C \cdot G$ & $\mathrm{U} \cdot \mathrm{A}$ \\
\hline 456 & $\mathrm{U}$ & G \\
\hline $457-458 \cdot 474-475$ & $\mathrm{UG} \cdot \mathrm{CA}$ & $\mathrm{AU} \cdot \mathrm{AU}$ \\
\hline $592 \cdot 647$ & $\mathrm{C} \cdot \mathrm{G}$ & $\mathrm{U} \cdot \mathrm{A}$ \\
\hline $614 \cdot 626$ & $A \cdot U$ & $\mathrm{C} \cdot \mathrm{G}$ \\
\hline 846 & A & $\mathrm{G}$ \\
\hline 1152 & A & $\mathrm{G}$ \\
\hline 1256 & $\mathrm{C}$ & $\mathbf{U}$ \\
\hline 1278 & $\mathrm{G}$ & $\mathbf{U}$ \\
\hline 1482 & $\mathrm{G}$ & A \\
\hline
\end{tabular}

${ }^{a} E$. coli numbering system (3). 
TABLE 6. Characteristics that distinguish strain $\mathrm{KoTa} 2^{\mathrm{T}}$ from the genera Ruminococcus and Carnobacterium

\begin{tabular}{|c|c|c|c|c|c|c|c|c|c|c|}
\hline \multirow[b]{2}{*}{ Taxon } & \multirow[b]{2}{*}{ Typical morphology } & \multirow{2}{*}{$\begin{array}{l}\text { Peptidoglycan } \\
\text { type }\end{array}$} & \multirow[b]{2}{*}{ Motility } & \multirow{2}{*}{$\begin{array}{c}\text { DNA } \\
\text { G+C } \\
\text { content } \\
\text { (mol\%) }\end{array}$} & \multirow{2}{*}{$\begin{array}{l}\text { Growth } \\
\text { on } \\
\text { cellulose }\end{array}$} & \multicolumn{3}{|c|}{ Major products } & \multirow{2}{*}{$\begin{array}{c}\text { Oxygen } \\
\text { tolerance }\end{array}$} & \multirow{2}{*}{$\begin{array}{l}\text { Minimum } \\
\text { growth } \\
\text { temp }\left({ }^{\circ} \mathrm{C}\right)\end{array}$} \\
\hline & & & & & & $\begin{array}{l}\text { Lactic } \\
\text { acid }\end{array}$ & $\begin{array}{l}\text { Succinic } \\
\text { acid }\end{array}$ & Hydrogen & & \\
\hline Ruminococcus ${ }^{a}$ & $\begin{array}{l}\text { Cocci or oval } \\
\text { cells with } \\
\text { pointed ends }\end{array}$ & $\mathrm{A} 1 \gamma, m$-Dpm-direct & $-b$ & $39-46$ & + or $-^{c}$ & - & + or $-^{c}$ & + & - & $20-30^{c}$ \\
\hline Strain KoTa2 ${ }^{\mathrm{T}}$ & Cocci & A4 $\alpha$, L-Lys-D-Asp & - & 45 & - & $+^{d}$ & - & - & + & 0 \\
\hline Carnobacterium $^{e}$ & $\begin{array}{l}\text { Short to medium- } \\
\text { length rods }\end{array}$ & $\mathrm{A} 1 \gamma, m$-Dpm-direct & + or $-^{c}$ & $33-37$ & - & + & - & - & + & 0 \\
\hline
\end{tabular}

${ }^{a}$ Data from references 4,7 , and 35 .

$b_{-}$, negative; + , positive.

${ }^{c}$ Strain or species dependent.

${ }^{d}$ Production of lactic acid depends on the $\mathrm{pH}$ of the culture.

${ }^{e}$ Data from references $5,9,11$, and 14 .

representatives of the major lines of lactic acid bacteria, members of the genus Ruminococcus, and Escherichia coli as an outgroup reference organism. Given that lower levels of relationships had to be resolved, the data for variable alignment positions (positions at which the sequences were invariant in less than $50 \%$ of the sequences in the entire data set) were deleted from the data set. The tree was corrected on the basis of the results of distance matrix and maximum-parsimony analyses of about $55016 \mathrm{~S}$ rRNA sequences from gram-positive bacteria with low DNA $\mathrm{G}+\mathrm{C}$ contents. The results of the majority of the analyses supported common roots for the genera Vagococcus and Enterococcus and the genera Lactococcus and Streptococcus. However, the branching order of these groups and the remaining major groups of lactic acid bacteria could not be determined unambiguously. This was indicated by multiple furcations in the tree. The deep branching of the genus Ruminococcus was supported by the results of all of the analyses which we performed.

Lactic acid production. Strain KoTa2 $2^{\mathrm{T}}$ formed L-lactate, as well as formate, acetate, and ethanol, from glucose in a mixed acid type of fermentation. Up to $2.0 \mathrm{~mol}$ of lactate was produced per mol of glucose fermented, depending on the growth $\mathrm{pH}$. A shift to lactate production from acetate and ethanol production with increasing acidity has been reported in a variety of microorganisms (31), and this shift is mediated by a Fru-1,6- $\mathrm{P}_{2}$-regulated LDH $(10,13)$. The Fru-1,6- $\mathrm{P}_{2}$ activation of LDH activity explains why lactate was not produced when the organism was grown on pyruvate, since Fru-1,6- $\mathrm{P}_{2}$, is not an intermediate of pyruvate catabolism. In pyruvate-grown cells the Fru-1,6- $\mathrm{P}_{2}$-dependent $\mathrm{LDH}$ activity increased as the acidity of the medium increased, although no lactate was produced. Thus, $\mathrm{pH}$ appears to control induction of this enzyme, while the enzyme activity is allosterically regulated by Fru-1,6$P_{2}$.

Oxygen tolerance. Strain $\mathrm{KoTa}_{2}{ }^{\mathrm{T}}$ could grow in the presence of yeast extract under microoxic to oxic conditions, but did not contain catalase or superoxide dismutase activities. Addition of hemin, hematin, or $\mathrm{MnCl}_{2}$ (all at a concentration of $10 \mu \mathrm{M}$ ) did not allow the organism to grow microaerobically in the absence of yeast extract; such additions are known to be components of catalase and pseudocatalase $(20,36)$. The basis of the microaerotolerance of strain $\mathrm{KoTa}_{2}^{\mathrm{T}}$ remains to be explained, and the role of yeast extract in conferring oxygen tolerance needs to be elucidated. Strain $\mathrm{KoTa}_{2}^{\mathrm{T}}$ apparently gained no additional metabolic energy during growth in the presence of oxygen; there were no significant changes in acetate production or specific growth yield. The amount of formate produced during growth on L-tartrate in the presence of oxygen was greatly reduced. Transfer of electrons to oxygen by lactic acid bacteria has been described previously $(11,32)$, and such a transfer can produce superoxide or $\mathrm{H}_{2} \mathrm{O}_{2}$. No superoxide dismutase activity has been found in the lactic acid bacteria, and although members of the genus Lactobacillus can have hematin-containing catalases $(36,37)$ or manganese-containing pseudocatalase activities (19), members of the genus Carnobacterium are catalase negative (11). Lactic acid bacteria can be oxygen tolerant, and members of the genus Carnobacterium can even grow in the presence of air (11). In contrast, Ruminococcus spp. are strict anaerobes $(4,7)$. In this respect, strain $\mathrm{KoTa}^{\mathrm{T}}$ is physiologically similar to the lactic acid bacteria, particularly members of the genus Carnobacterium, and is not like members of the genus Ruminococcus.

Distinguishing features of strain KoTa2 ${ }^{\mathrm{T}}$. Strain $\mathrm{KoTa}^{\mathrm{T}}$ can be distinguished from members of the genus Ruminococcus by the fact that it produces significant amounts of lactate under acidic conditions, by the fact that it does not produce significant amounts of hydrogen or succinate from glucose, by its oxygen tolerance, and by other characteristics (Table 6). Our comparative sequence analysis of the 16S rRNA gene showed that strain KoTa $2^{\mathrm{T}}$ is not related to members of the genus Ruminococcus and is closely related to members of the genus Carnobacterium. Strain $\mathrm{KoTa}^{\mathrm{T}}$ can be distinguished from members of the genus Carnobacterium by its coccal morphology and DNA base composition (45 mol\% G+C) (Carnobacterium spp. have short to medium-length, straight, slender, rod-shaped cells and DNA base compositions ranging from 33 to $37 \mathrm{~mol} \% \mathrm{G}+\mathrm{C}$ ) (Table 6) and by its unique signature nucleotides (Table 5). The peptidoglycan type of all previously described members of the genus Carnobacterium is type A $1 \gamma, m$-Dpm-direct $(5,9,14)$, while the peptidoglycan type of strain $\mathrm{KoTa}_{2}{ }^{\mathrm{T}}$ is type $\mathrm{A} 4 \alpha, \mathrm{L}-\mathrm{Lys}-\mathrm{D}-\mathrm{Asp}$. On the basis of the data described above, we propose that strain KoTa2, previously the type strain of $R$. pasteurii, should be reclassified in a new genus, Lactosphaera gen. nov., as the type strain of Lactosphaera pasteurii comb. nov. The description below is based on data from this study and a previous study (27).

Description of Lactosphaera gen. nov. Lactosphaera (Lac.to. sphae'ra. L. gen. n. lactis, milk [used because of its association with lactic acid fermentation]; Gr. fem. n. sphaira, a sphere; N.L. fem. n. Lactosphaera, a lactic acid-producing sphere). Lactosphaera cells are gram-positive, nonmotile, nonsporulating cocci. Aminopeptidase negative. The cell wall is a single thick layer that is about $25 \mathrm{~nm}$ thick. The peptidoglycan type is type A4 $\alpha$, L-Lys-D-Asp.

Fermentative chemoorganotrophic metabolism. Some organic acids (metabolized via pyruvate) and sugars are used as 
carbon and energy sources and are variously fermented to L-lactate, formate, acetate, ethanol, and $\mathrm{CO}_{2}$. No respiratory metabolism occurs with oxygen, fumarate, nitrate, or sulfur compounds. Not generally polysaccharolytic, although some sugar polymers support growth.

As determined by a 16S rDNA analysis, the genus Lactosphaera belongs to the group containing gram-positive lactic acid bacteria with low DNA $\mathrm{G}+\mathrm{C}$ contents and is closely related to the genus Carnobacterium, but is distinguished by key signature nucleotides, by its coccus-shaped cells, and by its higher DNA G+C content ( $45 \mathrm{~mol} \%$, compared with 33 to 37 mol\%).

Description of Lactosphaera pasteurii comb. nov. Lactosphaera pasteurii (pas.teu'ri.i. M.L. gen. n. pasteurii, referring to Louis Pasteur, who probably first enriched and observed this bacterium during studies on tartrate fermentation). L. pasteurii cells are cocci that form pairs or small irregular packets of cells. The cells are 1.0 to $1.5 \mu \mathrm{m}$ in diameter. No flagella are found.

Growth occurs under an air atmosphere in complex media. Growth occurs at 0 to $42^{\circ} \mathrm{C}$, at $\mathrm{pH} 5.5$ to 9.0 , and in the presence of $\mathrm{NaCl}$ concentrations up to $2 \%$ (wt/vol). Catalase and superoxide dismutase activities are absent. Biotin is required as a growth factor.

Nitrate, sulfate, sulfite, thiosulfate, sulfur, and fumarate are not reduced. The presence of oxygen can result in a shift to more oxidized fermentation end products, but this is not coupled to energy conservation. No cytochromes are formed.

The following growth substrates are utilized (L isomers of organic and amino acids and $\mathrm{D}$ isomers of sugars unless noted otherwise): L-tartrate, pyruvate, oxaloacetate, malate, citrate, mannitol, sorbitol, glucose, galactose, mannose, L-rhamnose, fructose, maltose, lactose, sucrose, cellobiose, raffinose, trehalose, sorbose, starch, oat spelt xylan, and laminarin (weak). D-Tartrate, meso-tartrate, xylose, ribose, arabinose, malonate, succinate, DL-3-hydroxybutyrate, lactate, amino acids, alcohols, chitin, gum karaya, carboxymethyl cellulose, amorphous cellulose, mannan, lichenan, gum locust bean, pullulan, arabinogalactan, and glycogen are not utilized.

L-Tartrate, pyruvate, and citrate are fermented to acetate and formate (and $\mathrm{CO}_{2}$ ). Glucose and other carbohydrates are fermented to L-lactate, acetate, formate, and ethanol. Lactate production increases under acidic growth conditions and is mediated by a Fru-1,6- $\mathrm{P}_{2}$-activated $\mathrm{LDH}$. $\mathrm{LDH}$ induction is controlled by $\mathrm{pH}$. Succinate production and $\mathrm{H}_{2}$ production are insignificant.

Negative for oxidase activity, urease activity, indole production, sulfide production from cysteine, and gelatin hydrolysis. Esculin is hydrolyzed. No growth occurs on acetate agar $(\mathrm{pH}$ 5.4).

The DNA base composition of strain $\mathrm{KoTa}^{\mathrm{T}}$ is $45 \mathrm{~mol} \%$ $\mathrm{G}+\mathrm{C}$.

The type strain is KoTa2 (= DSM 2381 = ATCC 35945), which was isolated from anoxic digestor sludge.

\section{ACKNOWLEDGMENTS}

We thank H. Hippe, Deutsche Sammlung von Mikroorganismen und Zellkulturen, Braunschweig, Germany, for providing unpublished data, the directors of the Thermophile Research Unit, University of Waikato, Hamilton, New Zealand, for access to facilities, and T. Ezaki, Gifu University School of Medicine, Gifu, Japan, for providing sequence data prior to publication.

P.H.J. gratefully acknowledges a UGC scholarship (in New Zealand) and a fellowship from the Alexander-von-Humboldt-Stiftung (in Germany). This work was supported in part by grant BIOT-CT910294(SSMA) from the European Economic Community.

\section{REFERENCES}

1. Atlas, R. M., and L. C. Parks. 1993. Handbook of microbiological media. CRC Press, Boca Raton, Fla.

2. Bergmeyer, H. U. 1974. Methoden der enzymatischen Analyse, 3rd ed. Verlag Chemie, Weinheim, Germany.

3. Brosius, J., T. J. Dull, D. D. Sleeter, and H. F. Noller. 1981. Gene organization and primary structure of a ribosomal RNA operon from Escherichia coli. J. Mol. Biol. 148:107-127.

4. Bryant, M. P. 1986. Genus Ruminococcus, p. 1093-1097. In P. H. A. Sneath N. S. Mair, M. E. Sharpe, and J. G. Holt (ed.), Bergey's manual of systematic bacteriology, vol. 2. Williams and Wilkins, Baltimore.

5. Collins, M. D., J. A. B. Farrow, B. A. Phillips, S. Ferusu, and D. Jones. 1987. Classification of Lactobacillus divergens, Lactobacillus piscicola, and some catalase-negative, asporogenous, rod-shaped bacteria from poultry in a new genus, Carnobacterium. Int. J. Syst. Bacteriol. 37:310-317.

6. Ezaki, T., N. Li, Y. Hashimoto, H. Miura, and H. Yamamoto. 1994. 16S ribosomal DNA sequences of anaerobic cocci and proposal of Ruminococcu hansenii comb. nov. and Ruminococcus productus comb. nov. Int. J. Syst. Bacteriol. 44:130-136.

7. Ezaki, T., H. Oyaizu, and E. Yabuuchi. 1992. The anaerobic gram-positive cocci, p. 1879-1892. In A. Balows, H. G. Trüper, M. Dworkin, W. Harder, and K. H. Schleifer (ed.), The prokaryotes, 2nd ed. Springer Verlag, Berlin.

8. Felsenstein, J. 1982. Numerical methods for inferring phylogenetic trees. $Q$. Rev. Biol. 57:379-404.

9. Franzmann, P. D., P. Höpfl, N. Weiss, and B. J. Tindall. 1991. Psychrotrophic, lactic acid-producing bacteria from anoxic waters in Ace Lake; Carnobacterium funditum $\mathrm{sp}$. nov. and Carnobacterium alterfunditum $\mathrm{sp}$. nov. Arch. Microbiol. 156:255-262.

10. Garvie, E. I. 1980. Bacterial lactate dehydrogenases. Microbiol. Rev. 44:106139.

11. Hammes, W. P., N. Weiss, and W. Holzapfel. 1992. The genera Lactobacillus and Carnobacterium, p. 1535-1594. In A. Balows, H. G. Trüper, M. Dworkin, W. Harder, and K. H. Schleifer (ed.), The prokaryotes, 2nd ed. Springer Verlag, Berlin.

12. Hippe, H. (Deutsche Sammlung von Mikroorganismen und Zellkulturen, Braunschweig, Germany). 1991. Personal communication.

13. Holland, R., and G. G. Pritchard. 1975. Regulation of the L-lactate dehydrogenase from Lactobacillus casei by fructose-1,6-diphosphate and metal ions. J. Bacteriol. 121:777-784.

14. Holzapfel, W. H., and E. S. Gerber. 1983. Lactobacillus divergens sp. nov., a new heterofermentative Lactobacillus species producing $\mathrm{L}(+)$-lactate. Syst. Appl. Microbiol. 4:522-534.

15. Janssen, P. H. 1991. Fermentation of L-tartrate by a newly isolated gramnegative bacterium. Antonie Leeuwenhoek 59:191-198.

16. Janssen, P. H., and C. G. Harfoot. 1990. Isolation of a Citrobacter species able to grow on malonate under strictly anaerobic conditions. J. Gen. Microbiol. 136:1037-1042.

17. Janssen, P. H., and C. G. Harfoot. 1990. Ilyobacter delafieldii sp. nov., a metabolically restricted anaerobic bacterium fermenting PHB. Arch. Microbiol. 154:253-259.

18. Janssen, P. H., and B. Schink. 1993. Pathway of poly- $\beta$-hydroxybutyrate degradation by Ilyobacter delafieldii. Biodegradation 4:179-185.

19. Johnston, M. A., and E. A. Delwiche. 1962. Catalase of the Lactobacillaceae. J. Bacteriol. 83:936-938.

20. Kono, Y., and I. Fridovich. 1983. Isolation and characterization of the pseudocatalase of Lactobacillus plantarum. J. Biol. Chem. 258:6015-6019.

21. Lamed, R., and J. G. Zeikus. 1980 . Glucose fermentation pathway of Thermoanaerobium brockii. J. Bacteriol. 141:1251-1257.

22. Larsen, N., G. J. Olsen, B. L. Maidak, M. J. McCaughey, R. Overbeek, T. J. Macke, T. L. Marsh, and C. R. Woese. 1993. The Ribosomal Database Project. Nucleic Acids Res. 21:3021-3023.

23. Ludwig, W. Unpublished data.

24. Neefs, J. M., P. De Rijk, Y. Van de Peer, S. Chapelle, and R. De Wachter. 1993. Compilation of small ribosomal subunit RNA structures. Nucleic Acids Res. 21:3025-3049.

25. Rainey, F. A., P. H. Janssen, H. W. Morgan, and E. Stackebrandt. 1993. A biphasic approach to the determination of the phenotypic and genotypic diversity of some anaerobic, cellulolytic, thermophilic, rod-shaped bacteria. Antonie Leeuwenhoek 64:341-355.

26. Rainey, F. A., and E. Stackebrandt. 1993. 16S rDNA analysis reveals phylogenetic diversity among the polysaccharolytic clostridia. FEMS Microbiol. Lett. 113:125-128.

27. Schink, B. 1984. Fermentation of tartrate enantiomers by anaerobic bacteria, and description of two new species of strict anaerobes, Ruminococcus pasteurii and Ilyobacter tartaricus. Arch. Microbiol. 139:409-414.

28. Schleifer, K. H., and O. Kandler. 1972. Peptidoglycan types of bacterial cell walls and their taxonomic implications. Bacteriol. Rev. 36:407-477.

29. Smibert, R. M., and N. R. Krieg. 1981. General characterization, p. 409-443. In P. Gerhardt, R. G. E. Murray, R. N. Costilow, E. W. Nester, W. A. Wood, N. R. Krieg, and G. B. Phillips (ed.), Manual of methods for general bacteriology. American Society for Microbiology, Washington, D.C

30. Springer, N., W. Ludwig, R. Amann, H. J. Schmidt, H. D. Görtz, and K. H. 
Schleifer. 1993. Occurrence of fragmented 16S rRNA in an obligate bacterial endosymbiont of Paramecium caudatum. Proc. Natl. Acad. Sci. USA 90: 9892-9895.

31. Stouthamer, A. H. 1978. Energy-yielding pathways, p. 389-462. In L. N. Ornston and J. R. Sokatch (ed.), The bacteria. A treatise on structure and function, vol. 6. Bacterial diversity. Academic Press, New York.

32. van Beelen, P., J. S. van der Hoeven, M. H. de Jong, and H. Hoogendoorn. 1986. The effect of oxygen on the growth and acid production of Streptococcus mutans and Streptococcus sanguis. FEMS Microbiol. Ecol. 38:25-30.

33. Vance, P. G., B. B. Keele, and K. V. Rajagopalan. 1972. Superoxide dismutase from Streptococcus mutans. Isolation and characterization of two forms of the enzyme. J. Biol. Chem. 247:4782-4786.
34. Wallbanks, S., A. J. Martinez-Murcia, J. L. Fryer, B. A. Phillips, and M. D. Collins. 1990. 16S rRNA sequence determination for members of the genus Carnobacterium and related lactic acid bacteria and description of Vagococcus salmoniarum sp. nov. Int. J. Syst. Bacteriol. 40:224-230.

35. Weiss, N. 1981. Cell wall structure of anaerobic cocci. Rev. Inst. Pasteur Lyon 14:53-59.

36. Whittenbury, R. 1964 . Hydrogen peroxide formation and catalase activity in the lactic acid bacteria. J. Gen. Microbiol. 35:13-26.

37. Wolf, G., and W. P. Hammes. 1962. Effect of hematin on the activities of nitrite reductase and catalase in lactobacilli. Arch. Microbiol. 149:220224 . 